\title{
Shallow Ground-Water Quality in an Agricultural Area of the Lower Coastal Plain of South Carolina, 1997
}

\section{By Eric J. Reuber}

U.S. Geological Survey

Open-File Report 01-377

Prepared as part of the

National Water-Quality Assessment Program

Santee River Basin and Coastal Drainages Study Unit

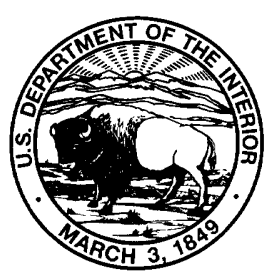

Columbia, South Carolina 2001 


\section{U.S. DEPARTMENT OF THE INTERIOR \\ GALE A. NORTON, Secretary}

\section{U.S. GEOLOGICAL SURVEY}

Charles G. Groat, Director

Use of trade, product, or firm names in this publication is for descriptive purposes only and does not imply endorsement by the U.S. Geological Survey

For additional information write to:

\section{District Chief}

U.S. Geological Survey

Suite 129

720 Gracern Road

Columbia, SC 29210-7651
Copies of this report can be purchased from:

U.S. Geological Survey Branch of Information Services Box 25286

Denver, CO 80225-0286 888-ASK-USGS

Additional information about water resources in South Carolina is available on the World Wide Web at http://sc.water.usgs.gov 


\section{FOREWORD}

The U.S. Geological Survey (USGS) is committed to serve the Nation with accurate and timely scientific information that helps enhance and protect the overall quality of life, and facilitates effective management of water, biological, energy, and mineral resources. Information on the quality of the Nation's water resources is of critical interest to the USGS because it is so integrally linked to the long-term availability of water that is clean and safe for drinking and recreation and that is suitable for industry, irrigation, and habitat for fishes and wildlife. Escalating population growth and increasing demands for these multiple water uses make water availability, now measured in terms of quantity and quality, even more critical to the long-term sustainability of our communities and ecosystems.

The USGS implemented the National Water-Quality Assessment (NAWQA) program to support national, regional, and local information needs and decisions related to water-quality management and policy. Shaped by and coordinated with ongoing efforts of other Federal, State, and local agencies, the NAWQA Program is designed to answer: What is the condition of our Nation's streams and ground water? How are the conditions changing over time? How do natural features and human activities affect the quality of streams and ground water, and where are those effects most pronounced? By combining information on water chemistry, physical characteristics, stream habitat, and aquatic life, the NAWQA Program aims to provide science-based insights for current and emerging water issues. Program results can contribute to informed decisions that result in practical and effective waterresource management and strategies that protect and restore water quality.

Since 1991, the NAWQA Program has implemented interdisciplinary assessments in more than 50 of the Nation's most important river basins and aquifers, referred to as "study units." Collectively, these study units account for more than 60 percent of the overall water use and population served by public-water supply, and are representative of the Nation's major hydrologic landscapes, priority ecological resources, and agricultural, urban, and natural sources of contamination.

Each assessment is guided by a nationally consistent study design and methods of sampling and analysis. The assessments thereby build local knowledge about water-quality issues and trends in a particular stream or aquifer while providing an understanding of how and why water quality varies regionally and nationally. The consistent, multiscale approach helps to determine if certain types of water-quality issues are isolated or pervasive, and allows direct comparisons of how human activities and natural processes affect water quality and ecological health in the Nation's diverse geographic and environmental settings. Comprehensive assessments on pesticides, nutrients, volatile organic compounds, trace metals, and aquatic ecology are developed at the national scale through comparative analyses of the study-unit findings.

The USGS places high value on the communication and dissemination of credible, timely, and relevant science so that the most recent and available knowledge about water resources can be applied in management and policy decisions. We hope this NAWQA publication will provide you the needed insights and information to meet your needs, and thereby foster increased awareness and involvement in the protection and restoration of our Nation's waters.

The NAWQA Program recognizes that a national assessment by a single program cannot address all water-resource issues of interest. External coordination at all levels is critical for a fully integrated understanding of watersheds and for cost-effective management, regulation, and conservation of our Nation's water resources. The program, therefore, depends extensively on the advice, cooperation, and information from other Federal, State, interstate, tribal, and local agencies, nongovernment organizations, industry, academia, and other stakeholder groups. The assistance and suggestions of all are greatly appreciated.

Robert M. Hirsch

Associate Director for Water 


\section{Contents}




\section{CONTENTS}

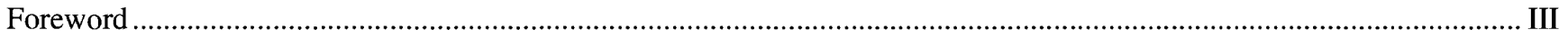

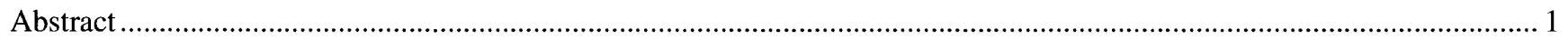

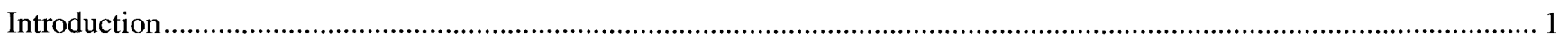

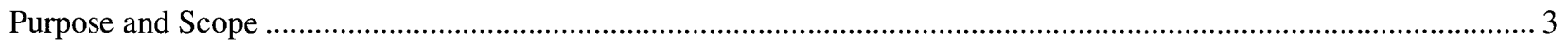

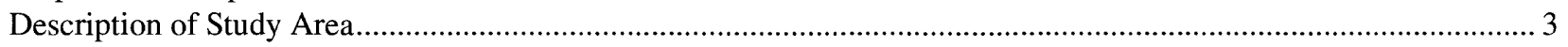

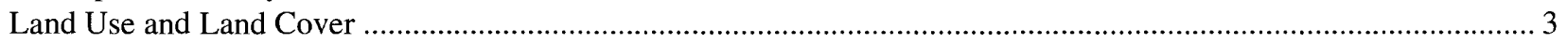

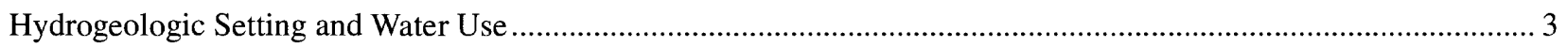

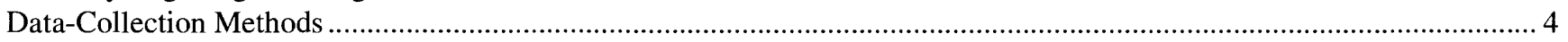

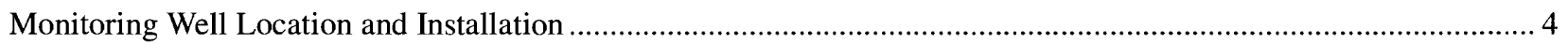

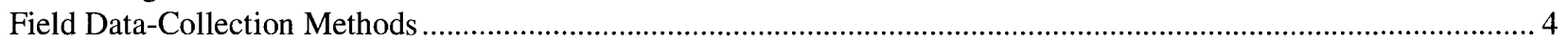

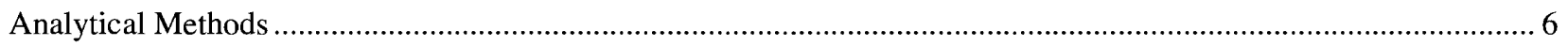

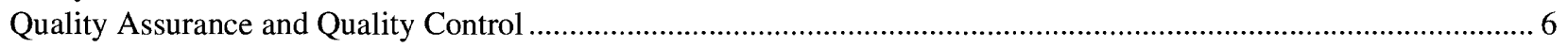

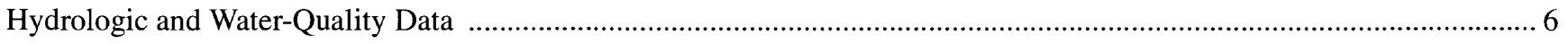

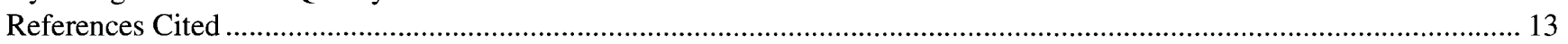

\section{FIGURE}

1. Map showing land use and locations of monitoring wells in the agricultural land-use study area, lower Coastal Plain of South Carolina, 1997.

\section{TABLES}

1. Land use in the agricultural land-use study area, lower Coastal Plain of South Carolina, 1994..................................... 3

2. Well characteristics and field properties for ground-water samples from 30 monitoring wells in the agricultural land-use study area, lower Coastal Plain of South Carolina, 1997 .......................................................................... 5

3. Concentrations of major ions in ground-water samples collected in the agricultural land-use study area, lower Coastal Plain of South Carolina, 1997

4. Concentrations of nutrients in ground-water samples collected in the agricultural land-use study area, lower Coastal Plain of South Carolina, 1997.

5. Concentrations of selected pesticides in ground-water samples collected in the agricultural land-use study area, lower Coastal Plain of South Carolina, 1997.

6. Results of quality-assurance and quality-control analyses in ground-water samples collected in the agricultural land-use study area, lower Coastal Plain of South Carolina, 1997... 
CONVERSION FACTORS, TEMPERATURE, AND VERTICAL AND HORIZONTAL DATUM

\begin{tabular}{rcl}
\hline Multiply & By & To obtain \\
\hline inch (in.) & 25.40 & millimeter \\
foot (ft) & 0.3048 & meter \\
pound (lb) & 0.4535 & kilogram \\
mile (mi) & 1.609 & kilometer \\
square mile (mi $\left.{ }^{2}\right)$ & 2.590 & square kilometer \\
\hline
\end{tabular}

Temperature can be converted between degrees Fahrenheit $\left({ }^{\circ} \mathrm{F}\right)$ and degrees Celsius $\left({ }^{\circ} \mathrm{C}\right)$ as follows: ${ }^{\circ} \mathrm{F}=\left({ }^{\circ} \mathrm{C} \times 9 / 5\right)+32{ }^{\circ} \mathrm{C}=\left({ }^{\circ} \mathrm{F}-32\right) \times 5 / 9$

Sea level refers to the National Geodetic Vertical Datum of 1929 (NGVD of 1929)--a geodetic datum derived from a general adjustment of the first-order level nets of the United States and Canada, formerly called Sea Level Datum of 1929.

Horizontal coordinate information is referenced to the North American Datum of 1988 (NAD88).

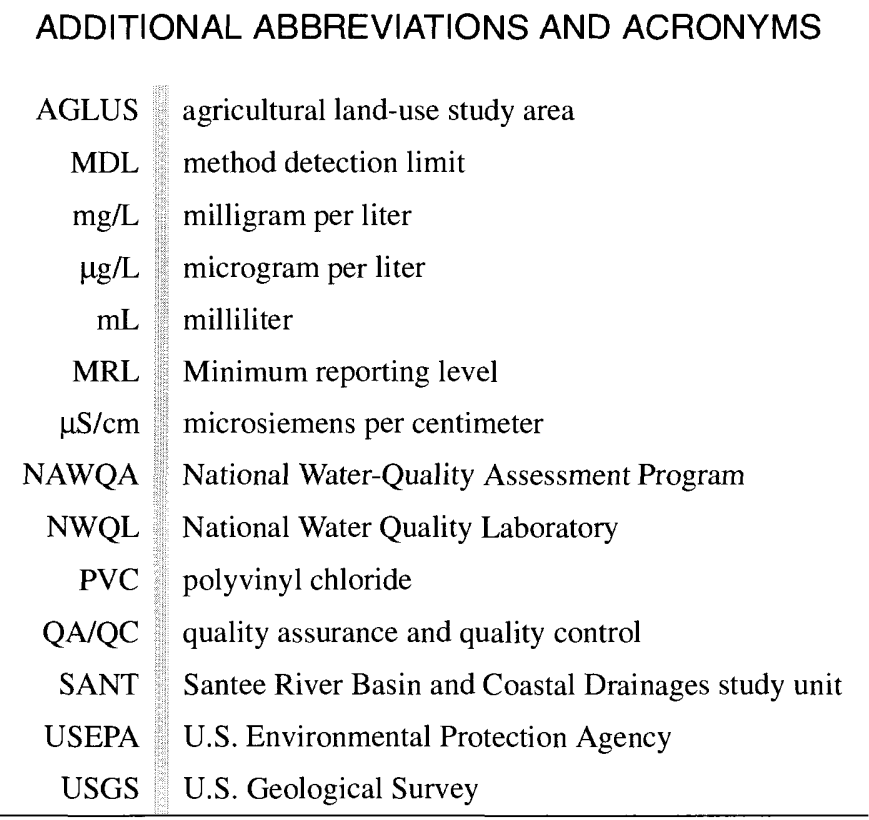




\title{
Shallow Ground-Water Quality in an Agricultural Area of the Lower Coastal Plain of South Carolina, 1997
}

\author{
By Eric J. Reuber
}

\begin{abstract}
Ground-water-quality samples were collected from 30 shallow monitoring wells located in agricultural areas of the lower Coastal Plain of South Carolina during the summer of 1997 as part of the U.S. Geological Survey National Water-Quality Assessment Program in the Santee River Basin and Coastal Drainages study unit. The wells were completed in sand to clayey sand sediments of the surficial aquifer and sampled one time for selected field properties, and nutrient, major ion, and pesticide concentrations. This report contains the results of the sampling effort.
\end{abstract}

\section{INTRODUCTION}

In 1991, the U.S. Geological Survey (USGS) implemented the National Water-Quality Assessment (NAWQA) Program. Long-term goals of the NAWQA Program include describing the status and trends in the quality of the Nation's surface- and ground-water resources and identifying major natural and anthropogenic factors that affect the quality of these water resources (Hirsch and others, 1988). To meet these goals, nationally consistent data useful to policy makers, scientists, and managers are being collected and analyzed at more than 50 of the Nation's largest river basins and aquifers, which are termed NAWQA study units.

The Santee River Basin and Coastal Drainages (SANT) study unit includes parts of the Coastal Plain, Piedmont, and Blue Ridge physiographic provinces in North and South Carolina (fig. 1). Assessment activities began in 1994. Although agriculture is not the predominant land use in the Coastal Plain of the SANT (table 1), it is a major land use of concern in relation to water quality. Activities associated with agriculture introduce a potential for nutrients and pesticides to leach into ground water or be discharged to surface water, either of which could impact drinkingwater supplies or cause impairment of surface water for designated uses. Historical water-quality data for the shallow aquifers in the SANT study unit are limited. To address these concerns, the USGS conducted an investigation of shallow ground-water quality in agricultural areas in the Coastal Plain of South Carolina as part of SANT study unit activities. The study area (fig. 1) is referred to throughout this report as the agricultural land-use study area (AGLUS). 


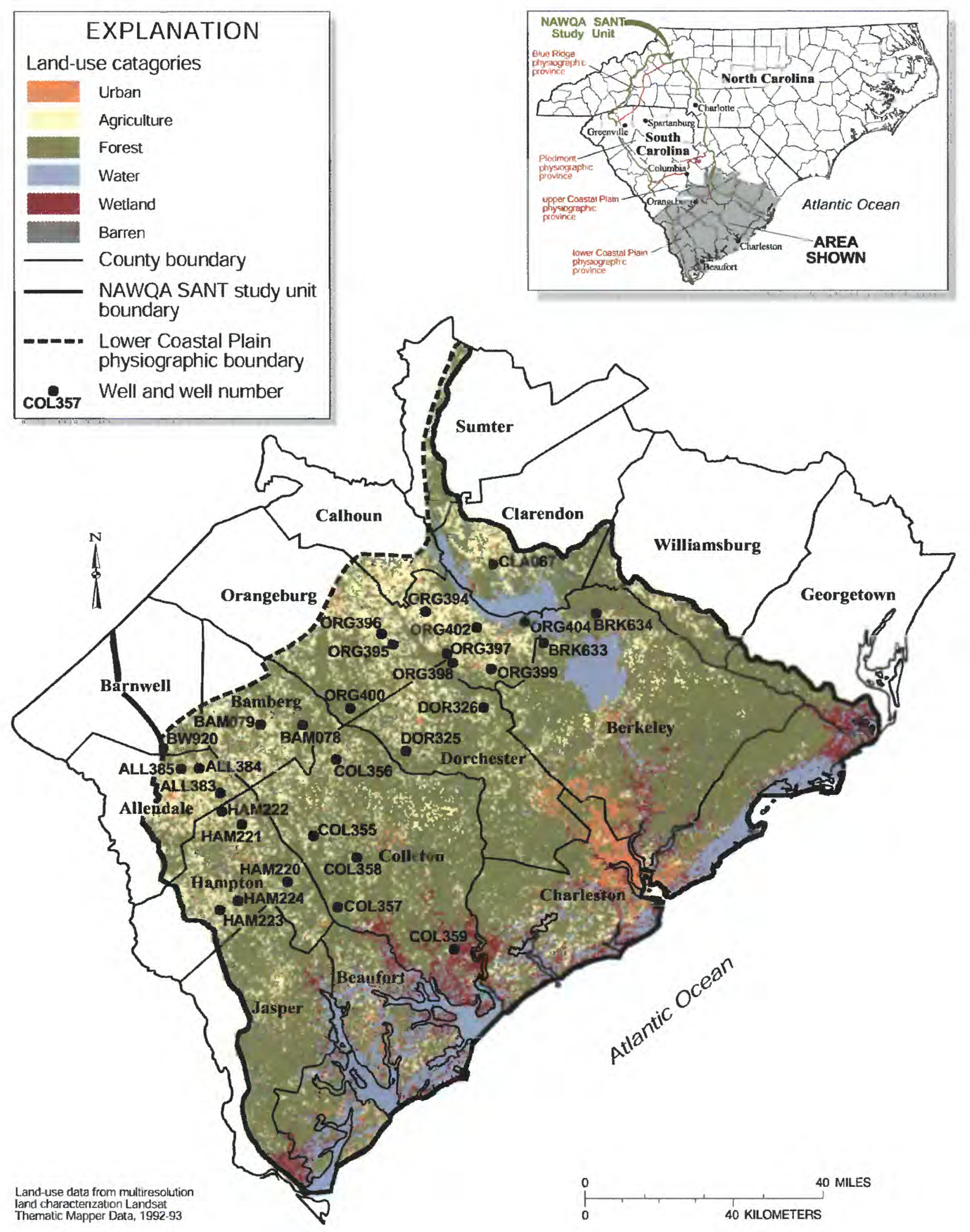

Figure 1. Land use and locations of monitoring wells in the agricultural land-use study area, lower Coastal Plain of South Carolina, 1997. [NAWQA, National Water-Quality Assessment Program; SANT, Santee River Basin and Coastal Drainages study unit.] 
Table 1. Land use in the agricultural land-use study area, lower Coastal Plain of South Carolina, 1994

[Data modified from U.S. Geological Survey, 1994]

\begin{tabular}{lcc}
\hline \multicolumn{1}{c}{ Land use } & Square miles & Percentage $^{1}$ \\
\hline Forest & 2,910 & 40.0 \\
Wetland & 2,060 & 28.3 \\
Agriculture & 1,720 & 23.7 \\
Water & 330 & 4.5 \\
Urban & 220 & 3.0 \\
Barren & 29 & 0.4 \\
\hline
\end{tabular}

${ }^{1}$ Total does not equal 100 percent due to rounding.

\section{Purpose and Scope}

This report presents ground-water-quality data collected from the surficial aquifer in an agricultural land-use area of the lower Coastal Plain of South Carolina. Thirty shallow monitoring wells (fig. 1) were installed in the surficial aquifer during the spring of 1997. Ground water was sampled once from each well during the summer of 1997 and analyzed for selected field properties, nutrients, major ions, and pesticides.

\section{Description of Study Area}

The SANT study unit (fig. 1) encompasses nearly $24,900 \mathrm{mi}^{2}$ in the Blue Ridge, Piedmont, and Coastal Plain physiographic provinces, and includes parts of North Carolina $\left(4,700 \mathrm{mi}^{2}\right)$ and South Carolina $\left(20,200 \mathrm{mi}^{2}\right)$. The SANT study unit contains agricultural lands, forests, wetlands, and five major metropolitan areas-Greenville, Spartanburg, Columbia, and Charleston, South Carolina, and Charlotte, North Carolina. The AGLUS, located in the lower Coastal Plain of South Carolina, is composed of all or parts of 16 counties (fig. 1) and covers approximately $7,270 \mathrm{mi}^{2}$. Average monthly temperatures in the lower Coastal Plain range from $50^{\circ} \mathrm{F}$ in December to $81{ }^{\circ} \mathrm{F}$ in July. Average annual precipitation for the AGLUS is about 50 inches (in.), and nearly 50 percent of the rainfall occurs between June and September (South Carolina Water Resources Commission, 1983).

\section{Land Use and Land Cover}

Land use in the AGLUS (table 1) is dominated by forests ( 40.0 percent), wetlands ( 28.3 percent), and agriculture (23.7 percent) (U.S. Geological Survey, 1994). Agriculture in the AGLUS is characterized by pastures and a diversity of crops, such as corn, soybeans, cotton, tobacco, and sorghum. Corn and soybeans, the most prevalent crops, are planted in approximately 20 percent of the AGLUS and are commonly rotated with each other (South Carolina Agricultural Statistics Service, 1998). Many of these crops are irrigated. Urban land represents 3 percent of total land use in the AGLUS study area. Urban areas and agriculture predominate in well-drained areas, whereas forests and wetlands are concentrated in and along stream floodplains and carolina bays. Forested lands include natural regrowth of previously logged and agricultural areas, intensively managed forests, and forested wetlands.

\section{Hydrogeologic Setting and Water Use}

Six major aquifers underlie the lower Coastal Plain and are used for domestic and agricultural purposes within the SANT study unit. In descending order, the aquifers are the surficial, Tertiary sand, Upper Floridan, Black Creek, Middendorf, and Cape Fear (Aucott and others, 1986). Several rural community supplies and almost all private domestic supplies in the AGLUS rely on wells that obtain water from the deeper aquifers. This investigation addresses only water-quality conditions in the shallow surficial aquifer.

The surficial aquifer is present throughout much of the lower Coastal Plain, and overlies the Upper Floridan aquifer in the eastern part and the Tertiary sand aquifer in the western part of the AGLUS (Aucott and others, 1986). The surficial aquifer consists of sand, clay, and shells. In general, the thickness of these sediments ranges from 15 to $30 \mathrm{ft}$, except in Charleston County where the thickness ranges from 40 to $65 \mathrm{ft}$.

Sediments forming the surficial aquifer in the lower Coastal Plain generally consist of quartz sand and minor amounts of silicate minerals interbedded with silt and clay lenses. The clay lenses commonly contain pyrite and lignite. These sediments are 
generally acidic, having a median $\mathrm{pH}$ value of about 4.5; $\mathrm{pH}$ generally increases with depth, reflecting the presence of carbonate minerals in shell material found in deeper sediments (Aucott and others, 1986).

The surficial aquifer is recharged by precipitation. Shallow ground water discharges through localized flow paths to nearby streams, ponds, and ditches. In many agricultural areas, natural drainage patterns have been altered with tile drains, drainage ditches, and by channelization of streambeds to improve agricultural land use. Water levels in the surficial aquifer range from land surface in floodplain areas to approximately $20 \mathrm{ft}$ below land surface.

Most major municipalities in the SANT, and hence the AGLUS, rely on surface water as the major source for drinking-water supplies. Public and domestic supplies account for about two-thirds of the withdrawal, and agriculture represents nearly the other third (Stringfield, 1987).

\section{DATA-COLLECTION METHODS}

Standardized protocols within the NAWQA Program were used to choose well locations and sample ground water at selected sites (Koterba and others, 1995). Thirty wells were installed during May and June 1997 and water-quality sampling was completed between July and September 1997.

\section{Monitoring Well Location and Installation}

Wells were located in areas within or directly adjacent to agricultural areas. Drilling locations for monitoring wells were selected based on NAWQA well site-selection criteria (Lapham and others, 1995). The thirty wells were located in a randomized, areally distributed pattern in the AGLUS area of the lower Coastal Plain by using a site-selection program described by Scott (1990). Ancillary land-use and land-cover data were collected for each well according to Koterba (1998). Field reconnaissance and aerial photos were used to collect detailed landuse data within $1,600 \mathrm{ft}$ of each well. In agricultural areas, land uses were subdivided into individual crop types present at the time of the site visit. In addition to specific crops, agricultural areas could include livestock farms, roads, orchards, and farm-related infrastructures that include houses, small gardens, barns, silos, and service roads on the farm.
Boreholes were drilled using 3-in-diameter solid-stem augers. No core recovery was available with this method of drilling and only limited cuttings were recovered. Wells were constructed with threaded 2-in-diameter, 5- or 10-ft-long schedule 40 polyvinyl chloride (PVC) casing. Casings were equipped with 5 - or 10 -ft-long, slotted (0.010 in.) PVC screens tipped with flush-threaded PVC drivepoints. The tops of the screens generally were placed 2 to $5 \mathrm{ft}$ below the water table. In cases where natural sand did not completely fill the borehole annular space surrounding the well screen, commercially prepared washed sand was added to a level approximately $2 \mathrm{ft}$ above the top of the well screen. The remaining annular space was grouted with bentonite pellets to within $2 \mathrm{ft}$ of land surface. The top $2 \mathrm{ft}$ of each borehole was grouted to land surface with mortar. To protect the PVC wellhead, 3-in-diameter schedule 40 steel outer casings with locking caps were set into the mortar. All wells were constructed in accordance with South Carolina Department of Health and Environmental Control (1985) guidelines and NAWQA Program protocols for monitoring wells (Lapham and others, 1995). Well development took place within 15 days of installation by using a surge plunger or bailer to force water to flow in and out of the screened interval by moving the plunger or bailer up and down in the well casing. Well construction data are provided in table 2 .

\section{Field Data-Collection Methods}

Wells were sampled for a variety of constituents. In addition to field properties (water temperature, specific conductance, dissolved-oxygen concentration, and $\mathrm{pH}$ ), water samples were analyzed for selected major ions, nutrients, and pesticides. Prior to sampling, at least three casing volumes of water were pumped from the wells. Stability of the water chemistry was verified through periodic measurements of water temperature, specific conductance, dissolved-oxygen concentration, and $\mathrm{pH}$ while purging the wells. Samples were collected using Teflon, Viton, and stainless-steel tubing and fittings. Water samples were shipped to the USGS National Water Quality Laboratory (NWQL) in Denver, Colorado, following NAWQA protocols (Koterba and others, 1995). 
Table 2. Well characteristics and field properties for ground-water samples from 30 monitoring wells in the agricultural land-use study area, lower Coastal Plain of South Carolina, 1997

$\left[{ }^{\circ} \mathrm{C}\right.$, Celsius; $\mu \mathrm{S} / \mathrm{cm}$, microsiemens per centimeter; $\mathrm{mg} / \mathrm{L}$, milligram per liter]

\begin{tabular}{|c|c|c|c|c|c|c|c|c|c|}
\hline $\begin{array}{c}\text { County } \\
\text { well } \\
\text { number } \\
\text { (fig. 1) }\end{array}$ & $\begin{array}{c}\text { U.S. } \\
\text { Geological } \\
\text { Survey } \\
\text { well number }\end{array}$ & $\begin{array}{l}\text { Land- } \\
\text { surface } \\
\text { elevation at } \\
\text { well, in feet } \\
\text { above sea } \\
\text { level }\end{array}$ & $\begin{array}{c}\text { Well } \\
\text { depth, } \\
\text { in feet } \\
\text { belowland } \\
\text { surface }\end{array}$ & $\begin{array}{l}\text { Screened } \\
\text { interval, } \\
\text { in feet } \\
\text { below land } \\
\text { surface }\end{array}$ & $\begin{array}{l}\text { Water } \\
\text { depth, } \\
\text { in feet } \\
\text { below land } \\
\text { surface }\end{array}$ & $\begin{array}{c}\text { Water } \\
\text { temperature, } \\
\left({ }^{\circ} \mathrm{C}\right)\end{array}$ & $\begin{array}{c}\text { Specific } \\
\text { conductance, } \\
(\mu \mathrm{S} / \mathrm{cm} \text { at } \\
\left.25^{\circ} \mathrm{C}\right)\end{array}$ & $\begin{array}{c}\text { Dissolved } \\
\text { oxygen, } \\
\text { (mg/L) }\end{array}$ & $\begin{array}{c}\text { Water } \\
\mathrm{pH}\end{array}$ \\
\hline ALL383 & 330051081092501 & 16 & 17 & $12-17$ & 5.2 & 19.0 & 186 & 7.1 & 3.9 \\
\hline ALL384 & 330422081130601 & 16 & 20 & $15-20$ & 7.7 & 19.5 & 165 & 5.5 & 4.2 \\
\hline ALL385 & 330417081162201 & 21 & 21 & $16-21$ & 6.3 & 17.5 & 156 & 7.0 & 4.6 \\
\hline BAM078 & 331038080545601 & 13 & 17 & $12-17$ & 9.5 & 23.0 & 264 & 7.5 & 5.4 \\
\hline BAM079 & 331043081022101 & 15 & 30 & $20-30$ & 20.0 & 22.0 & 238 & 8.8 & 4.0 \\
\hline BRK633 & 332224080123601 & 88 & 20 & $16-20$ & 13.7 & 20.0 & 248 & 3.4 & 7.1 \\
\hline BRK634 & 332641080032201 & 78 & 20 & $15-20$ & 13.3 & 19.5 & 53 & 6.6 & 5.1 \\
\hline BW920 & 330715081192501 & 25 & 27 & $22-27$ & 18.8 & 17.0 & 161 & 7.9 & 4.6 \\
\hline CLA067 & 333358080213001 & 11 & 25 & $22-25$ & 22.3 & 20.0 & 160 & 8.1 & 4.1 \\
\hline COL355 & 325435080530601 & 80 & 30 & $25-30$ & 18.3 & 19.0 & 190 & 7.4 & 4.4 \\
\hline COL356 & 330540080490701 & 10 & 18 & $13-18$ & 7.1 & 18.5 & 8.3 & 7.3 & 7.7 \\
\hline COL357 & 324412080485501 & 52 & 25 & $15-25$ & 16.8 & 21.0 & 69 & 7.8 & 4.2 \\
\hline COL358 & 325129080453601 & 84 & 17 & $12-17$ & 6.4 & 23.0 & 114 & 1.9 & 4.1 \\
\hline COL359 & 323759080283701 & 13 & 13 & $3-13$ & 5.4 & 18.0 & 202 & 1.4 & 4.4 \\
\hline DOR325 & 330656080365201 & 84 & 15 & $10-15$ & 8.2 & 24.0 & 224 & 5.8 & 6.1 \\
\hline DOR326 & 331305080231301 & 90 & 18 & $13-18$ & 12.4 & 21.5 & 92 & 5.7 & 4.3 \\
\hline HAM220 & 324754080573801 & 85 & 20 & $10-20$ & 8.9 & 21.0 & 76 & 5.9 & 5.0 \\
\hline HAM221 & 325618081054101 & 11 & 17 & $12-17$ & 12.2 & 27.5 & 98 & 3.4 & 4.6 \\
\hline HAM 222 & 325812081090901 & 10 & 24 & $19-24$ & 14.7 & 20.5 & 220 & 9.7 & 4.1 \\
\hline HAM223 & 324349081092801 & 10 & 17 & $12-17$ & 11.1 & 22.0 & 31 & 5.2 & 4.6 \\
\hline HAM224 & 324507081061901 & 11 & 13 & $3-13$ & 10.2 & 22.5 & 48 & 0.5 & 5.1 \\
\hline ORG394 & 332706080332001 & 15 & 17 & $7-17$ & 9.4 & 21.5 & 42 & 5.7 & 4.6 \\
\hline ORG395 & 332355080410401 & 15 & 19 & $9-19$ & 13.7 & 21.0 & 438 & 4.4 & 4.0 \\
\hline ORG396 & 332219080390501 & 13 & 13 & $9-13$ & 9.8 & 23.5 & 239 & 5.3 & 4.0 \\
\hline ORG397 & 332056080293501 & 85 & 22 & $17-22$ & 11.2 & 22.0 & 248 & 5.0 & 6.7 \\
\hline ORG398 & 331934080283701 & 88 & 21 & $16-21$ & 10.8 & 22.5 & 59 & 0.2 & 5.0 \\
\hline ORG399 & 331842080215301 & 92 & 21 & $16-21$ & 13.7 & 21.5 & 270 & 5.8 & 3.8 \\
\hline ORG400 & 331303080464101 & 14 & 27 & $22-27$ & 5.9 & 20.0 & 322 & 0.4 & 7.5 \\
\hline ORG402 & 332446080242201 & 12 & 19 & $14-19$ & 12.8 & 21.0 & 67 & 3.5 & 4.4 \\
\hline ORG404 & 332534080155701 & 78 & 21 & $16-21$ & 8.4 & 21.0 & 234 & 0.2 & 6.4 \\
\hline
\end{tabular}




\section{Analytical Methods}

Ground-water samples collected for this study were analyzed using methods described by Fishman and Friedman (1985), Brenton and Arnett (1993), Zaugg and others (1995), and Werner and others (1996). The USGS NWQL reports all analytical concentrations if all quality-control and methods criteria are met. The minimum concentration of a constituent that can be identified, measured, and reported with 99 percent confidence that the analyte concentration is greater than zero for a given matrix containing the analyte is called the method detection limit (MDL) (U.S. Geological Survey, 1999). At the MDL concentration, the risk of a false positive is predicted to be no more than 1 percent. Pesticides that are positively identified at concentrations less than the MDL are reported by the NWQL as estimated values. Major ions, nutrients, and dissolvedorganic carbon are reported with minimum reporting levels (MRLs), which take into account MDLs and are based on the laboratory's best judgement of the concentration that can be reliably reported using a given analytical method (U.S. Geological Survey, 1999).

\section{Quality Assurance and Quality Control}

In addition to the samples collected from each of 30 wells, an additional 10 percent of samples were processed to ensure quality assurance/quality control (QA/QC) during the sampling and analytical processes. Three field blanks and one replicate sample were collected in accordance with NAWQA protocols (Koterba and others, 1995). Blanks aid in evaluating possible contamination by the equipment. Replicates aid in analyzing the precision of the sampling techniques and laboratory methods. The NWQL maintains its own internal program of blank, replicate, and spike samples to assure accurate water-quality analyses (Pritt and Raese, 1995).

\section{HYDROLOGIC AND WATER-QUALITY DATA}

Water from each of 30 wells was collected during the summer of 1997 and analyzed for field properties and inorganic and organic constituents. Results of field-measured properties are listed in table 2. Concentrations of the major ions, calcium, magnesium, sodium, potassium, chloride, sulfate, fluoride, and silica, are listed in table 3. Results of selected nutrient and pesticide analyses are listed in tables 4 and 5, respectively. Quality assurance/quality control data are listed in table 6. 
Table 3. Concentrations of major ions in ground-water samples collected in the agricultural land-use study area, lower Coastal Plain of South Carolina, 1997

[Concentrations in milligrams per liter; ND, not detected]

\begin{tabular}{|c|c|c|c|c|c|c|c|c|}
\hline $\begin{array}{l}\text { County well } \\
\text { number } \\
\text { (fig. 1) }\end{array}$ & Calcium & Magnesium & Sodium & Potassium & Chloride & Sulfate & Fluoride & Silica \\
\hline ALL383 & 3.1 & 11 & 3.1 & 0.36 & 20 & 0.52 & 0.12 & 6.2 \\
\hline ALL384 & 7.9 & 7.6 & 4.1 & 2.5 & 16 & 0.24 & ND & 6.2 \\
\hline BAM078 & 19 & 12 & 0.7 & 4.5 & 4.3 & 24 & ND & 2.2 \\
\hline BAM079 & 7.4 & 11 & 3.2 & 1.1 & 15 & 0.4 & ND & 6.3 \\
\hline BRK633 & 45 & 1 & 3.6 & 1.3 & 6.8 & 10 & ND & 8.1 \\
\hline BRK634 & 3 & 0.86 & 4.2 & 1.6 & 7.9 & 1.3 & ND & 13 \\
\hline COL356 & 39 & 3.9 & 2.9 & 0.82 & 12 & 3.3 & 0.21 & 4.6 \\
\hline COL357 & 0.83 & 2.3 & 4.7 & 0.39 & 11 & 0.1 & ND & 7.6 \\
\hline COL358 & 0.83 & 1.1 & 7.9 & 0.93 & 23 & 0.27 & ND & 12 \\
\hline COL359 & 13 & 1.5 & 15 & 0.45 & 23 & 49 & 0.37 & 44 \\
\hline DOR325 & 30 & 0.83 & 6.6 & 0.5 & 6.8 & 0.6 & 0.22 & 11 \\
\hline DOR326 & 1.8 & 2.5 & 6.2 & 1.2 & 8.9 & 1.5 & ND & 7 \\
\hline HAM 220 & 2.3 & 0.53 & 7.7 & 2.3 & 12 & 1.8 & ND & 19 \\
\hline ORG395 & 8.7 & 7.1 & 40 & 6 & 52 & 16 & 0.45 & 26 \\
\hline ORG396 & 14 & 6.8 & 3.2 & 1.1 & 16 & 0.32 & 0.29 & 8.3 \\
\hline ORG397 & 49 & 1.5 & 4.5 & 0.29 & 6.8 & 1.6 & 0.14 & 5.5 \\
\hline ORG398 & 3.7 & 0.36 & 3.6 & 0.12 & 10 & 0.74 & ND & 24 \\
\hline ORG399 & 7.8 & 5.9 & 1.9 & 21 & 20 & 0.51 & ND & 5.3 \\
\hline ORG399* & 7.7 & 6.5 & 2.0 & 20 & 20 & 0.46 & ND & 5.4 \\
\hline ORG400 & 58 & 1 & 9.7 & 0.42 & 8.6 & 18 & 0.13 & 16 \\
\hline ORG402 & 1.3 & 1.9 & 6.9 & 0.5 & 9.6 & 1 & ND & 7.1 \\
\hline ORG404 & 37 & 1.1 & 7.1 & 1.5 & 12 & 4 & ND & 10 \\
\hline
\end{tabular}

*Replicate sample. 
Table 4. Concentrations of nutrients in ground-water samples collected in the agricultural land-use study area, lower Coastal Plain of South Carolina, 1997

[Concentrations in milligrams per liter; ND, not detected]

\begin{tabular}{|c|c|c|c|c|c|c|}
\hline $\begin{array}{l}\text { County well } \\
\text { number } \\
\text { (fig. 1) }\end{array}$ & $\begin{array}{l}\text { Nitrogen, } \\
\text { nitrite plus } \\
\text { nitrate }\end{array}$ & $\begin{array}{l}\text { Nitrogen, } \\
\text { nitrite }\end{array}$ & $\begin{array}{l}\text { Nitrogen, } \\
\text { ammonia }\end{array}$ & $\begin{array}{c}\text { Nitrogen, } \\
\text { ammonia plus } \\
\text { organic }\end{array}$ & $\begin{array}{l}\text { Dissolved } \\
\text { phosphorus }\end{array}$ & $\begin{array}{l}\text { Phosphorus, } \\
\text { orthophosphate }\end{array}$ \\
\hline ALL383 & 13.0 & ND & ND & ND & ND & 0.055 \\
\hline ALL384 & 14.0 & ND & ND & ND & ND & 0.078 \\
\hline ALL385 & 12.7 & ND & ND & ND & 0.025 & 0.068 \\
\hline ВАM078 & 16.8 & ND & ND & ND & ND & ND \\
\hline BAM079 & 17.4 & ND & ND & ND & ND & ND \\
\hline BRK633 & 3.54 & ND & ND & ND & 0.044 & 0.054 \\
\hline BRK634 & 1.40 & ND & 0.037 & ND & 0.017 & ND \\
\hline BW920 & 12.9 & ND & ND & ND & ND & 0.019 \\
\hline CLA067 & 9.03 & ND & ND & ND & ND & ND \\
\hline COL355 & 13.2 & ND & ND & ND & ND & $\mathrm{ND}$ \\
\hline COL356 & 10.1 & ND & ND & 0.15 & 0.083 & 0.101 \\
\hline COL 357 & 2.32 & ND & 0.015 & ND & 0.021 & 0.022 \\
\hline COL358 & ND & ND & 0.027 & ND & ND & ND \\
\hline COL359 & ND & ND & ND & 0.35 & 0.367 & 0.389 \\
\hline DOR325 & 4.53 & ND & ND & ND & 0.019 & 0.029 \\
\hline DOR326 & 4.60 & ND & ND & ND & ND & ND \\
\hline HAM 220 & 2.06 & ND & 0.042 & ND & ND & ND \\
\hline HAM221 & 6.48 & ND & ND & ND & ND & ND \\
\hline HAM222 & 16.0 & ND & ND & ND & ND & ND \\
\hline HAM 223 & ND & ND & ND & ND & ND & ND \\
\hline HAM224 & 0.453 & ND & ND & ND & ND & ND \\
\hline ORG394 & 2.37 & ND & ND & ND & ND & ND \\
\hline ORG395 & 22.6 & 0.030 & ND & ND & ND & ND \\
\hline ORG396 & 18.1 & 0.054 & 0.017 & ND & ND & ND \\
\hline ORG397 & 2.21 & ND & ND & ND & ND & ND \\
\hline ORG398 & ND & ND & 0.036 & ND & 0.035 & 0.040 \\
\hline ORG399 & 17.3 & ND & 0.017 & ND & ND & ND \\
\hline ORG399* & 18.1 & 0.01 & 0.020 & ND & ND & ND \\
\hline ORG400 & 0.34 & 0.014 & ND & $\mathrm{ND}$ & 0.013 & 0.040 \\
\hline ORG402 & 2.45 & ND & 0.020 & ND & ND & ND \\
\hline ORG404 & 6.88 & 0.02 & ND & ND & ND & 0.014 \\
\hline
\end{tabular}

*Replicate sample. 
Table 5. Concentrations of selected pesticides in ground-water samples collected in the agricultural land-use study area, lower Coastal Plain of South Carolina, 1997

[Concentrations in micrograms per liter; ND, not detected]

County well
number
(fig. 1)

ALL383 Deethyl atrazine (0.003), atrazine (0.002), alachlor (0.002), acetochlor $(0.002)$

ALL384 Deethyl atrazine (0.019), atrazine (0.014), simazine (0.002), alachlor (0.008), acetochlor (0.002), tebuthiuron (1.9), metolachlor (0.205)

ALL385 Deethyl atrazine (0.005), atrazine (0.004), simazine (0.007), alachlor $(0.002)$, acetochlor $(0.002)$, ethalfluralin $(0.005)$

BAM078 Deethyl atrazine (0.034), atrazine (0.075), bentazon (11.5), metolachlor $(0.018)$,

BAM079 Deethyl atrazine (0.005), atrazine $(0.014)$

BRK633 Deethyl atrazine (0.004), atrazine (0.004), dieldrin (0.004)

BRK634 Deethyl atrazine (0.008)

BW920 Deethyl atrazine $(0.072)$, atrazine $(0.010)$, metolachlor $(0.041)$, diazinon $(0.005)$, terbacil $(0.03)$, carbofuran $(0.01)$, diuron $(0.02)$

CLA067 ND

COL355 Deethyl atrazine $(0.005)$, atrazine $(0.003)$

COL356 Deethyl atrazine (0.063), atrazine (0.005)

COL357 Deethyl atrazine $(0.004)$

COL358 ND

COL359 ND

DOR325 Deethyl atrazine (0.002), atrazine (0.002), metolachlor $(0.002)$

DOR326 Deethyl atrazine $(0.019)$, atrazine $(0.011)$, prometon $(0.009)$

HAM220 ND

HAM221 Deethyl atrazine (0.004), trifluralin (0.005), tebuthiuron $(0.066)$

HAM222 Aldicarb sulfone (0.12)

HAM223 ND

HAM224 ND

ORG394 Deethyl atrazine (0.001)

ORG395 Deethyl atrazine (0.001)

ORG396 Metolachlor (0.003)

ORG397 ND

ORG398 Atrazine (0.001)

ORG399 Deethyl atrazine (0.005), atrazine (0.008)

ORG399* Deethyl atrazine $(0.004)$, atrazine $(0.007)$

ORG400 ND

ORG402 Fluometuron (0.18)

ORG404 Deethyl atrazine (0.003), atrazine $(0.001)$

*Replicate sample. 
Table 6. Results of quality-assurance and quality-control analyses in ground-water samples collected in the agricultural land-use study area, lower Coastal Plain of South Carolina, 1997

[Samples associated with wells ORG405 and ORG410 were collected during a similar study during the summer of 1997. An asterisk (*) indicates that the value shown is the actual concentration; all other values were less than the listed value because the compound was either absent from the sample or was present in such a small quantity that it could not be quantified. No value listed indicates constituent not sampled. $\mathrm{mg} / \mathrm{L}$, milligrams per liter; $\mu \mathrm{g} / \mathrm{L}$, micrograms per liter]

\begin{tabular}{|c|c|c|c|c|}
\hline \multirow{2}{*}{ Constituent } & \multicolumn{4}{|c|}{ County well number } \\
\hline & ORG405 & DOR326 & ORG410 & ORG402 \\
\hline Nitrogen ammonia, $\mathrm{mg} / \mathrm{L}$ & 0.02 & & $0.023 *$ & 0.015 \\
\hline Nitrogen, nitrite, $\mathrm{mg} / \mathrm{L}$ & 0.01 & & 0.01 & 0.01 \\
\hline Nitrogen ammonia plus organic, $\mathrm{mg} / \mathrm{L}$ & 0.1 & & 0.1 & 0.2 \\
\hline Nitrogen nitrite plus nitrate, $\mathrm{mg} / \mathrm{L}$ & $0.053^{*}$ & & 0.05 & 0.05 \\
\hline Phosphorus, mg/L & 0.01 & & 0.01 & 0.01 \\
\hline Phosphorus orthophosphate, $\mathrm{mg} / \mathrm{L}$ & 0.01 & & $0.012^{*}$ & 0.01 \\
\hline Calcium, mg/L & 0.02 & 0.02 & & $0.081 *$ \\
\hline Magnesium, mg/L & 0.01 & 0.01 & & 0.01 \\
\hline Sodium, mg/L & 0.2 & 0.2 & & 0.2 \\
\hline Potassium, $\mathrm{mg} / \mathrm{L}$ & 0.1 & 0.1 & & 0.1 \\
\hline Chloride, $\mathrm{mg} / \mathrm{L}$ & 0.1 & 0.1 & & 0.1 \\
\hline Sulfate, $\mathrm{mg} / \mathrm{L}$ & 0.1 & 0.1 & & 0.1 \\
\hline Fluoride, mg/L & 0.1 & 0.1 & & 0.1 \\
\hline Silica, $\mathrm{mg} / \mathrm{L}$ & 0.01 & 0.01 & & $0.087^{*}$ \\
\hline Manganese, $\mathrm{mg} / \mathrm{L}$ & $1.3^{*}$ & 1 & & $1.6^{*}$ \\
\hline Propachlor, $\mu \mathrm{g} / \mathrm{L}$ & 0.007 & 0.007 & & 0.007 \\
\hline Butylate, $\mu \mathrm{g} / \mathrm{L}$ & 0.002 & 0.002 & & 0.002 \\
\hline Bromacil, $\mu \mathrm{g} / \mathrm{L}$ & 0.035 & 0.035 & & 0.035 \\
\hline Simazine, $\mu g / L$ & 0.005 & 0.005 & & 0.005 \\
\hline Prometon, $\mu \mathrm{g} / \mathrm{L}$ & 0.018 & 0.018 & & 0.018 \\
\hline Deethyl atrazine, $\mu \mathrm{g} / \mathrm{L}$ & 0.002 & 0.002 & & 0.002 \\
\hline Cyanazine, $\mu \mathrm{g} / \mathrm{L}$ & 0.004 & 0.004 & & 0.004 \\
\hline Fonofos, $\mu \mathrm{g} / \mathrm{L}$ & 0.003 & 0.003 & & 0.003 \\
\hline Alpha BHC, $\mu \mathrm{g} / \mathrm{L}$ & 0.002 & 0.002 & & 0.002 \\
\hline p.p' DDE, $\mu g / L$ & 0.006 & 0.006 & & 0.006 \\
\hline Dicamba, $\mu \mathrm{g} / \mathrm{L}$ & 0.035 & 0.035 & & 0.035 \\
\hline Linuron, $\mu \mathrm{g} / \mathrm{L}$ & 0.018 & 0.018 & & 0.018 \\
\hline $\mathrm{MCPA}, \mu \mathrm{g} / \mathrm{L}$ & 0.05 & 0.05 & & 0.05 \\
\hline $\mathrm{MCPB}, \mu \mathrm{g} / \mathrm{L}$ & 0.035 & 0.035 & & 0.035 \\
\hline Methiocarb, $\mu \mathrm{g} / \mathrm{L}$ & 0.026 & 0.026 & & 0.026 \\
\hline Propoxur, $\mu \mathrm{g} / \mathrm{L}$ & 0.035 & 0.035 & & 0.035 \\
\hline Bentazon, $\mu \mathrm{g} / \mathrm{L}$ & 0.014 & 0.014 & & 0.014 \\
\hline 2,4-DB, $\mu g / L$ & 0.035 & 0.035 & & 0.035 \\
\hline Fluometuron, $\mu \mathrm{g} / \mathrm{L}$ & 0.035 & 0.035 & & 0.035 \\
\hline Oxamyl, $\mu \mathrm{g} / \mathrm{L}$ & 0.018 & 0.018 & & 0.018 \\
\hline Chlorpyrifos, $\mu \mathrm{g} / \mathrm{L}$ & 0.004 & 0.004 & & 0.004 \\
\hline
\end{tabular}


Table 6. Results of quality-assurance and quality-control analyses in ground-water samples collected in the agricultural land-use study area, lower Coastal Plain of South Carolina, 1997 (Continued)

[Samples associated with wells ORG405 and ORG410 were collected during a similar study during the summer of 1997. An asterisk $\left({ }^{*}\right)$ indicates that the value shown is the actual concentration; all other values were less than the listed value because the compound was either absent from the sample or was present in such a small quantity that it could not be quantified. No value listed indicates constituent not sampled. $\mathrm{mg} / \mathrm{L}$, milligrams per liter; $\mu \mathrm{g} / \mathrm{L}$, micrograms per liter]

\begin{tabular}{|c|c|c|c|c|}
\hline \multirow{2}{*}{ Constituent } & \multicolumn{4}{|c|}{ County well number } \\
\hline & ORG405 & DOR326 & ORG410 & ORG402 \\
\hline Lindane, $\mu \mathrm{g} / \mathrm{L}$ & 0.004 & 0.004 & & 0.004 \\
\hline Dieldrin, $\mu \mathrm{g} / \mathrm{L}$ & 0.001 & 0.001 & & 0.001 \\
\hline Metolachlor, $\mu \mathrm{g} / \mathrm{L}$ & 0.002 & 0.002 & & 0.002 \\
\hline Malathion, $\mu \mathrm{g} / \mathrm{L}$ & 0.005 & 0.005 & & 0.005 \\
\hline Parathion, $\mu \mathrm{g} / \mathrm{L}$ & 0.004 & 0.004 & & 0.004 \\
\hline Diazinon. $\mu \mathrm{g} / \mathrm{L}$ & 0.002 & 0.002 & & 0.002 \\
\hline Atrazine, $\mu \mathrm{g} / \mathrm{L}$ & 0.001 & 0.001 & & 0.001 \\
\hline $2,4-\mathrm{D}, \mu \mathrm{g} / \mathrm{L}$ & 0.035 & 0.035 & & 0.035 \\
\hline $2,4,5-\mathrm{T}, \mu \mathrm{g} / \mathrm{L}$ & 0.035 & 0.035 & & 0.035 \\
\hline Silvex, $\mu \mathrm{g} / \mathrm{L}$ & 0.021 & 0.021 & & 0.021 \\
\hline Alachlor, $\mu \mathrm{g} / \mathrm{L}$ & 0.002 & 0.002 & & 0.002 \\
\hline Triclopyr, $\mu \mathrm{g} / \mathrm{L}$ & 0.05 & 0.05 & & 0.05 \\
\hline Propham, $\mu \mathrm{g} / \mathrm{L}$ & 0.035 & 0.035 & & 0.035 \\
\hline Acetochlor, $\mu \mathrm{g} / \mathrm{L}$ & 0.002 & 0.002 & & 0.002 \\
\hline Picloram, $\mu \mathrm{g} / \mathrm{L}$ & 0.05 & 0.05 & & 0.05 \\
\hline Oryzalin, $\mu \mathrm{g} / \mathrm{L}$ & 0.019 & 0.019 & & 0.019 \\
\hline Norflurazon, $\mu \mathrm{g} / \mathrm{L}$ & 0.024 & 0.024 & & 0.024 \\
\hline Neburon, $\mu \mathrm{g} / \mathrm{L}$ & 0.015 & 0.015 & & 0.015 \\
\hline 1-naphthol, $\mu \mathrm{g} / \mathrm{L}$ & 0.007 & 0.007 & & 0.007 \\
\hline Methomyl, $\mu \mathrm{g} / \mathrm{L}$ & 0.017 & 0.017 & & 0.017 \\
\hline Fenuron, $\mu \mathrm{g} / \mathrm{L}$ & 0.013 & 0.013 & & 0.013 \\
\hline Esfenvalerate, $\mu \mathrm{g} / \mathrm{L}$ & 0.019 & 0.019 & & 0.019 \\
\hline DNOC, $\mu \mathrm{g} / \mathrm{L}$ & 0.035 & 0.035 & & 0.035 \\
\hline Diuron, $\mu \mathrm{g} / \mathrm{L}$ & 0.02 & 0.02 & & 0.02 \\
\hline Dinoseb, $\mu \mathrm{g} / \mathrm{L}$ & 0.035 & 0.035 & & 0.035 \\
\hline Dichlorprop, $\mu \mathrm{g} / \mathrm{L}$ & 0.032 & 0.032 & & 0.032 \\
\hline Dichlobenil, $\mu \mathrm{g} / \mathrm{L}$ & 0.02 & 0.02 & & 0.02 \\
\hline Dacthal, mono-acid, $\mu \mathrm{g} / \mathrm{L}$ & 0.017 & 0.017 & & 0.017 \\
\hline Clopyralid, $\mu \mathrm{g} / \mathrm{L}$ & 0.05 & 0.05 & & 0.05 \\
\hline Chlorothalonil, $\mu \mathrm{g} / \mathrm{L}$ & 0.035 & 0.035 & & 0.035 \\
\hline Chloramben, $\mu \mathrm{g} / \mathrm{L}$ & 0.011 & 0.011 & & 0.011 \\
\hline 3-hydroxycarbofuran, $\mu \mathrm{g} / \mathrm{L}$ & 0.014 & 0.014 & & 0.014 \\
\hline Carbofuran, $\mu \mathrm{g} / \mathrm{L}$ & 0.028 & 0.028 & & 0.028 \\
\hline Carbaryl, $\mu \mathrm{g} / \mathrm{L}$ & 0.008 & 0.008 & & 0.008 \\
\hline Bromoxynil, $\mu \mathrm{g} / \mathrm{L}$ & 0.035 & 0.035 & & 0.035 \\
\hline
\end{tabular}


Table 6. Results of quality-assurance and quality-control analyses in ground-water samples collected in the agricultural land-use study area, lower Coastal Plain of South Carolina, 1997 (Continued)

[Samples associated with wells ORG405 and ORG410 were collected during a similar study during the summer of 1997. An asterisk $\left({ }^{*}\right)$ indicates that the value shown is the actual concentration; all other values were less than the listed value because the compound was either absent from the sample or was present in such a small quantity that it could not be quantified. No value listed indicates constituent not sampled. $\mathrm{mg} / \mathrm{L}$, milligrams per liter; $\mu \mathrm{g} / \mathrm{L}$, micrograms per liter]

\begin{tabular}{|c|c|c|c|c|}
\hline \multirow{2}{*}{ Constituent } & \multicolumn{4}{|c|}{ County well number } \\
\hline & ORG405 & DOR326 & ORG410 & ORG402 \\
\hline Aldicarb, $\mu \mathrm{g} / \mathrm{L}$ & 0.016 & 0.016 & & 0.016 \\
\hline Aldicarb sulfone, $\mu \mathrm{g} / \mathrm{L}$ & 0.016 & 0.016 & & 0.05 \\
\hline Aldicarb sulfoxide, $\mu \mathrm{g} / \mathrm{L}$ & 0.021 & 0.021 & & 0.021 \\
\hline Acifluorfen, $\mu \mathrm{g} / \mathrm{L}$ & 0.035 & 0.035 & & 0.035 \\
\hline Metribuzin, sencor, $\mu \mathrm{g} / \mathrm{L}$ & 0.004 & 0.004 & & 0.004 \\
\hline 2,6-diethylaniline, $\mu \mathrm{g} / \mathrm{L}$ & 0.003 & 0.003 & & 0.003 \\
\hline Trifluralin, $\mu \mathrm{g} / \mathrm{L}$ & 0.002 & 0.002 & & 0.002 \\
\hline Ethalfluralin, $\mu \mathrm{g} / \mathrm{L}$ & 0.004 & 0.004 & & 0.004 \\
\hline Phorate, $\mu \mathrm{g} / \mathrm{L}$ & 0.002 & 0.002 & & 0.002 \\
\hline Terbacil, $\mu \mathrm{g} / \mathrm{L}$ & 0.007 & 0.007 & & 0.007 \\
\hline Linuron, $\mu \mathrm{g} / \mathrm{L}$ & 0.002 & 0.002 & & 0.002 \\
\hline Methyl parathion, $\mu \mathrm{g} / \mathrm{L}$ & 0.006 & 0.006 & & 0.006 \\
\hline EPTC, $\mu \mathrm{g} / \mathrm{L}$ & 0.002 & 0.002 & & 0.002 \\
\hline Pebulate, $\mu \mathrm{g} / \mathrm{L}$ & 0.004 & 0.004 & & 0.004 \\
\hline Tebuthiuron, $\mu \mathrm{g} / \mathrm{L}$ & 0.01 & 0.01 & & 0.01 \\
\hline Molinate, $\mu \mathrm{g} / \mathrm{L}$ & 0.004 & 0.004 & & 0.004 \\
\hline Ethoprop, $\mu \mathrm{g} / \mathrm{L}$ & 0.003 & 0.003 & & 0.003 \\
\hline Benfluralin, $\mu \mathrm{g} / \mathrm{L}$ & 0.002 & 0.002 & & 0.002 \\
\hline Carbofuran, $\mu \mathrm{g} / \mathrm{L}$ & 0.003 & 0.003 & & 0.003 \\
\hline Terbufos, $\mu \mathrm{g} / \mathrm{L}$ & 0.013 & 0.013 & & 0.013 \\
\hline Pronamide, $\mu \mathrm{g} / \mathrm{L}$ & 0.003 & 0.003 & & 0.003 \\
\hline Disulfoton, $\mu \mathrm{g} / \mathrm{L}$ & 0.017 & 0.017 & & 0.017 \\
\hline Triallate, $\mu \mathrm{g} / \mathrm{L}$ & 0.001 & 0.001 & & 0.001 \\
\hline Propanil, $\mu \mathrm{g} / \mathrm{L}$ & 0.004 & 0.004 & & 0.004 \\
\hline Carbaryl, $\mu \mathrm{g} / \mathrm{L}$ & 0.003 & 0.003 & & 0.003 \\
\hline Thiobencarb, $\mu \mathrm{g} / \mathrm{L}$ & 0.002 & 0.002 & & 0.002 \\
\hline $\mathrm{DCPA}, \mu \mathrm{g} / \mathrm{L}$ & 0.002 & 0.002 & & 0.002 \\
\hline Pendimethalin, $\mu \mathrm{g} / \mathrm{L}$ & 0.004 & 0.004 & & 0.004 \\
\hline Napropamide, $\mu \mathrm{g} / \mathrm{L}$ & 0.003 & 0.003 & & 0.003 \\
\hline Propargite, $\mu \mathrm{g} / \mathrm{L}$ & 0.013 & 0.013 & & 0.013 \\
\hline Methyl Azinphos, $\mu \mathrm{g} / \mathrm{L}$ & 0.001 & 0.001 & & 0.001 \\
\hline Permethrin, Cis, $\mu \mathrm{g} / \mathrm{L}$ & 0.005 & 0.005 & & 0.005 \\
\hline
\end{tabular}




\section{REFERENCES CITED}

Aucott, W.R., Davis, M.E., and Speiran, G.K., 1986, Geohydrologic framework for the Coastal Plain aquifers of South Carolina: U.S. Geological Survey WaterResources Investigations Report 85-4271, 7 sheets.

Brenton, R.W., and Arnett, T.L., 1993, Methods of analysis by the U.S. Geological Survey National Water Quality Laboratory--Determination of dissolved organic carbon by UV-promoted persulfate oxidation and infrared spectrometry: U.S. Geological Survey Open-File Report 92-480, $12 \mathrm{p}$.

Fishman, M.J., and Friedman, L.C., 1985, Methods for determination of inorganic substances in water and fluvial sediments: U.S. Geological Survey Open-File Report 85-495, 709 p.

Hirsch, R.M., Alley, W.M., and Wilber, W.G., 1988 , Concepts for a National Water-Quality Assessment Program: U.S. Geological Survey Circular 1021, 42 p.

Koterba, M.T., 1998, Ground-water data-collection protocols and procedures for the National Water-Quality Assessment Program: Collection, documentation, and compilation of required site, well, subsurface, and landscape data for wells: U.S. Geological Survey WaterResources Investigations Report 98-4107, 70 p.

Koterba, M.T., Wilde, F.D., and Lapham, W.W., 1995, Ground-water data-collection protocols and procedures for the National Water-Quality Assessment Program: Collection and documentation of water-quality samples and related data: U.S. Geological Survey Open-File Report 95-399, 113 p.

Lapham, W.W., Wilde, F.D., and Koterba, M.T., 1995, Ground-water data-collection protocols and procedures for the National Water-Quality Assessment Program: Selection, installation, and documentation of wells, and collection of related data: U.S. Geological Survey Open-File Report 95-398, 69 p.
Pritt, J.W., and Raese, J.W., 1995, Quality assurance/quality control manual, National Water Quality Laboratory: U.S. Geological Survey Open-File Report 95-443, 35 p.

Scott, J.C., 1990, Computerized stratified random siteselection approaches for design of ground-water-quality sampling network: U.S. Geological Survey WaterResources Investigations Report 90-4101, 109 p.

South Carolina Agricultural Statistics Service, 1998, South Carolina agricultural statistics; crops, livestock, and poultry 1996-1997: Columbia, $84 \mathrm{p}$.

South Carolina Department of Health and Environmental Control, 1985, South Carolina well standards and regulations: R61-71, 15 p.

South Carolina Water Resources Commission, 1983, South Carolina State water assessment: South Carolina Water Resources Commission Report no. 140. 367 p.

Stringfield, W.J., 1987, National Water Summary--Groundwater quality: South Carolina: U.S. Geological Survey Water Supply Paper 2350, p. 453-456.

U.S. Geological Survey, 1994, Multi-resolution land characteristics dataset, CD-ROM.

1999, Glossary: Accessed April 26, 1999, at URL http:// wwwnwql.cr.usgs.gov/USGS/Catalog/ glossary.html.

Werner, S.L., Burkhardt, M.R., and DeRusseau, S.N., 1996, Methods of analysis by the U.S. Geological Survey National Water Quality Laboratory--Determination of pesticides in water by Carbopak-B solid-phase extraction and high-performance liquid chromatography: U.S. Geological Survey Open-File Report 96-216, 42 p.

Zaugg, S.D., Sandstrom, M.W., Smith, S.G., and Fehlberg, K.M., 1995, Methods of analysis by the U.S. Geological Survey National Water Quality Laboratory--Determination of pesticides in water by $\mathrm{C}-18$ solid-phase extraction and capillary-column gas chromatography/mass spectrophotometry with selected-ion monitoring: U.S. Geological Survey Open-File Report 95-181, 49 p. 